\title{
Proceeding
}

Supplementary Issue: Rio 2016 Olympic Games First Anniversary Special Edition. Olympic Studies Forum, 4-5 August 2017. Santa Úrsula University. Rio de Janeiro, Brazil

\section{Laboratory performance: Doping in Olympic sports and Rio 2016 Games}

\author{
RANDEANTONY C. NASCIMENTO01,2,3,4 $\checkmark$, AILTON FERNANDO S. DE OLIVEIRA ${ }^{1,2,3}$, JUAN JOSÉ \\ FERNÁNDEZ ROMERO ${ }^{4,5}$, SARAH CRISTINA MONTES CANUTO1,2,3 \\ 1SCENARIOS / UFS Group, Brazil \\ ${ }^{2}$ Research Center for Sports and Leisure Policies of Sergipe - CDPPEL, Brazil \\ ${ }^{3}$ Federal University of Sergipe, Brazil \\ ${ }^{4}$ University of La Coruña, Spain \\ ${ }^{5}$ National Institute of Physical Education - INEF GALÍCIA, Spain
}

\begin{abstract}
Doping is defined by the World Anti-Doping Agency Code as the use of substances or methods capable of artificially increasing sports performance, whether they are potentially harmful to athletes health or to his opponents, or to the game spirit. The Olympic Sport deals daily with this competitor "off the beaten track" of the highest competence. This article was based on the reports on the anti-doping control situation in the Olympic Games in Brazil issued by the specialist of the US Congressional Research Service, the IAAF sanctioned positive athletics report, of the International Olympic Committee that dealt with the fight against doping and health promotion of athletes, the Independent Observer Reports of the World Anti-Doping Agency and the Anti-Doping Division of the Court of Arbitration for Sport. A special highlight was the doping cases orchestrated by the Russia Athletic Federation, as well as the efforts of institutions responsible for the fight against doping in the protection of clean athletes. The fight against doping in the Olympic Games in Brazil was classified as the worst anti-doping in the history of games, based on the volunteers organization and the effectiveness of the tests performed. The World Anti-Doping Agency indicated that less than half of the planned tests were conducted at the Rio 2016 Olympic Games. Key words: DOPING, ANTIDOPING, OLYMPIC GAMES, ATHLETES, RIO 2016.
\end{abstract}

\section{Cite this article as:}

Nascimento, R.C., De Oliveira, A.F.S., Fernández Romero, J.J. \& Montes Canuto, S.C. (2018). Laboratory performance: Doping in Olympic sports and Rio 2016 Games. Journal of Human Sport and Exercise, 13(1proc), S99-S115. doi:https://doi.org/10.14198/jhse.2018.13.Proc1.09

Corresponding author. Scenarios - Federal University of Sergipe, Brasil. http://orcid.org/0000-0002-0344-4171

E-mail: randy@ufs.com

Supplementary Issue: Rio 2016 Olympic Games First Anniversary Special Edition. Olympic Studies Forum, 4-5 August 2017. Santa Úrsula University. Rio de Janeiro, Brazil.

JOURNAL OF HUMAN SPORT \& EXERCISE ISSN 1988-5202

(c) Faculty of Education. University of Alicante

doi:10.14198/jhse.2018.13.Proc1.09 


\section{Rendimiento de Laboratorio: Dopaje en deportes olímpicos y Juegos de Rio 2016}

\section{RESUMEN}

El dopaje está definido por el Código de la Agencia Mundial Antidopaje, como el uso de sustancias o métodos capaces de aumentar artificialmente el rendimiento deportivo, ya sean potencialmente perjudiciales para la salud del atleta o de sus adversarios, o al espíritu del juego. Sin embargo, el Deporte Olímpico convive diariamente con este competidor "fuera de las pistas" de la más alta competencia. Este artículo se basó en los informes sobre la situación de control antidopaje en los Juegos Olímpicos en Brasil emitidos por especialistas de investigación del congreso norteamericano, de los informes de casos positivos en atletismo sancionados por la IAAF, del Comité Olímpico Internacional que versó sobre la lucha contra el dopaje y promoción de la salud de los atletas, de los informes de Observadores Independientes de la Agencia Mundial Antidoping y de la división antidoping del Tribunal de Arbitraje para el Deporte. Un destacado especial ha sido hecho para los casos de dopaje orquestados por la Federación Atlética Rússa, además de los esfuerzos de las instituciones responsables del combate al dopaje en la protección de los atletas limpios. El combate al dopaje en los Juegos Olímpicos de Brasil fue clasificado como el peor antidopaje de la historia de los juegos, con base en la organización de los voluntarios y la efectividad de las pruebas realizadas. La Agencia Mundial Antidoping indicó que menos de la mitad de las pruebas planificadas se realizaron en los Juegos Olímpicos Río 2016. Palabras clave: DOPAJE, ANTIDOPING, JUEGOS OLÍMPICOS, ATLETAS, RIO 2016. 


\section{INTRODUCTION}

One of the most important contentions that the Olympic Sports (OS) faces is not in the courts, fields, lanes or swimming pools, it is not part of the specific training of the coach, the incessant search for the best strategy for the best athletes, statistics for performance human, aero and hydrodynamic material goes much further, it occurs in doping design and manipulation laboratories.

The doping world never sleeps or gives truce, chemists from all over the world continue to work with new substances to produce positive effects on athletes' performance and not to be detected in the doping controls. Lawyers specialized in doping cases are prepared to find the "gaps" in international and national legislations governing the matter and sports, along with that extends a whole network of traffic that try daily on any price to market their products.

The reason is that there is a lot at stake, the difference between gold and silver, between a world record and a personal best, lies in a fraction of a second with a lot of cash involved. All sport superpowers understand this and invest countless amounts of money knowing they can not lose. These great powers always mention that they have the best scientific methods to discover the best athletes with the perfect innate characteristics, who have the best conditions of training, however it is known that along with this great structure are also the best doctors and the most powerful drugs, now with state incentive, now for individual commitment, doping is a present and striking figure in sports podiums and high performance sports shows.

Table 1. Doping Statistics in the Olympic Games - 1968 to 2012.

\begin{tabular}{llccc}
\hline Year & Place & Number drugs tests & Number of reported doping cases & $\%$ of reported doping cases \\
\hline 2012 & London & 5,051 & 9 & $0.18 \%$ \\
2008 & Beijing & 4,770 & 25 & $0.52 \%$ \\
2004 & Athens & 3,667 & 26 & $0.74 \%$ \\
2000 & Sydney & 2,359 & 11 & $0.47 \%$ \\
1996 & Atlanta & 1,923 & 2 & $0.10 \%$ \\
1992 & Barcelona & 1,848 & 5 & $0.27 \%$ \\
1988 & Seoul & 1,598 & 10 & $0.63 \%$ \\
1984 & Los Angeles & 1,507 & 12 & $0.80 \%$ \\
1980 & Moscow & 645 & 0 & $0.00 \%$ \\
1976 & Montreal & 786 & 11 & $1.40 \%$ \\
1972 & Munich & 2,079 & 7 & $0.34 \%$ \\
1968 & Mexico City & 667 & 119 & $0.15 \%$ \\
--- & Total & 26,900 & $0.44 \%$ \\
\hline
\end{tabular}


Table 2. Olympic Games doping cases by country, 1968-2010.

\begin{tabular}{|c|c|}
\hline $\begin{array}{l}\text { Number of Reported } \\
\text { Doping Cases }\end{array}$ & Olympic Doping Cases by Country -1968-2010 \\
\hline 10 & Austria \\
\hline 9 & Greece, Russia \\
\hline 8 & USA \\
\hline 7 & Bulgaria, Hungary \\
\hline 5 & Poland, Spain \\
\hline 4 & Germany, Sweden \\
\hline 3 & Great Britain, Mongolia, Norway, Ukraine \\
\hline 2 & $\begin{array}{c}\text { Belarus, Brazil, Canada, Czechoslovakia, India, Ireland, Italy, Japan, Puerto Rico, } \\
\text { Romania }\end{array}$ \\
\hline 1 & $\begin{array}{c}\text { Afghanistan, Algeria, Armenia, Australia, Bahrain, China, Croatia, Finland, Ireland, Iran, } \\
\text { Kenya, Latvia, Lebanon, Lithuania, Moldova, Monaco, Morocco, Myanmar, Netherlands, } \\
\text { North Korea, Slovakia, Turkey, Unified Team (CIS), USSR, Uzbekistan, Vietnam, West } \\
\text { Germany }\end{array}$ \\
\hline 127 & Total \\
\hline
\end{tabular}

Source: Report of the International Olympic Committee (IOC), 2014.

\section{RIO 2016: SAFETY, ENVIRONMENT, AND PROBLEMS WITH DOPING}

In the report issued before the 2016 Olympic Games, by Halchin and Rollins, coordinatorsand specialists in the US Congressional Research Service, which we are now debating, is about the concerns that US leaders and athletes, and other nations with anti-doping control at the Rio 2016 Games. They asked whether the organizations in charge of protecting clean athletes would be up to the task in Brazil. What fueled this concern were the revelations that the Russian track and field team were involved in a doping scheme orchestrated by the Russian Athletics Federation. (Halchin \& Rollins, 2016).

The report also pointed out that the World Anti-Doping Agency (WADA) was slow in responding when took notice of the claims orchestrated as early as 2010 pointed that there were "multiple warnings about doping generated by Russia" over the years and suggested that possible conflicts of interest could have played a role in WADA's slow response.

Concerns that other Russian sports could also be contaminated by state-orchestrated doping were validated in July 2016 with the publication of the first part of a report by Richard McLaren to WADA (McLaren, 2016a) describing, among other things, how Russian sports organizations and authorities manipulated samples of Russian athletes in 2014, during the Winter Olympic Games in Sochi. 
Although the United States government is not directly involved in WADA or its anti-doping efforts, it provides support to the agency, especially when its interests are under threat.

As signatories to the Copenhagen Declaration (WADA, 2003, 2015) on Anti-Doping in Sport, they support WADA and the World Anti-Doping Code (CODE)which includes financial support through membership dues (began payment in 2003 and by the year 2016, the US had transferred approximately $\$ 25$ million).(Halchin \& Rollins, 2016).

With all this investment made and feeling threatened by the allegations involving Russia and WADA's antidoping role, the Senate Committee on Trade, Science, and Transportation, as well as the House Energy and Commerce Committee begin to act. On 20 June 2016, the chairman of the Senate commission noted that WADA had been informed in 2010 that the Russian athletes were involved in a doping scheme orchestrated by the government and that WADA's independence had been called into question. It was necessary to take sides in the matter. (Halchin \& Rollins, 2016).

Representatives of US Olympic athletes "invited" WADA to expand their research into other sports in Russia and other countries. The Energy and Commerce Committee of the House expressed similar concerns in a letter dated July 12, 2016 to the President of the International Olympic Committee (IOC), acknowledging the work that the IOC and WADA had done to increase efforts to ensure that athletes competed in sports free of doping. One of the challenges identified by the committee is that "neither WADA nor IOC are functionally organized to achieve the goal of eradicating doping in sport." This concern extends until the Rio 2016 Olympic Games. (Halchin \& Rollins, 2016).

\section{THE RUSSIAN ATHLETICS FEDERATION AND DOPING BUY TICKETS FOR RIO 2016}

The Guardian Journal, on December 3, 2014, a documentary screened on German television claiming "the existence of a sophisticated and well-established doping system sponsored by the Russian state with its athletic federation." (Oltermann, P. 2014).

As a result, WADA formed an Independent Commission (IC) for the investigation, which began in January 2015, concluded with the publication of two reports, the first focusing on allegations of the German TV documentary. The conclusions sended in November 2015 report were (McLaren, 2016a):

1. There is a deep-rooted "culture of deception", which means the acceptance of fraud at all levels is widespread and longstanding.

2. The exploitation of athletes is acceptable, resulting in unethical behavior and practices, becoming the norm.

3. Many Russian athletes have participated in the consistent and systematic use of performance-enhancing drugs.

4. Physicians, trainers and laboratory personnel have been involved in systematic fraud.

The report also included two warnings: although there were reliable indications that other sports in Russia had doping problems, the IC stated that these sports were outside the scope of what had been directed at the investigation. The commission also stated that "Russia is not the only country, nor athletics the only sport, facing the problem of doping orchestrated in sport." The delivery of the report in November 2015 was 
immediately followed by responses from the International Association of Athletics Federations (IAAF), and WADA. The IAAF provisionally suspended the Russian Athletic Federation (ARAF) as a member of the IAAF with immediate effect. (IAAF, 2015).

A significant consequence of this suspension was the prohibition of athletes and support staff of the Russian Federation from competing in international competitions, including Rio 2016 Olympic Games. WADA's response was to provisionally suspend the Moscow Anti-Doping Center and recommend that the center's head, Dr. Grigory Rodchenkov, was removed permanently (he immediately resigned). Shortly after, it assessed the compliance of the Russian Anti-Doping Agency (RUSADA) with the World Anti-Doping Code. In a press release, WADA announced that RUSADA was not in compliance with the Code. (CAS, 2016).

The IAAF Council met to consider whether ARAF had fulfilled the conditions for reintegration. The report of the IAAF Working Group to the Council stated that several verification criteria had not been met and included several recommendations, all of which were accepted by the IAAF Board. In line with the recommendations, the IAAF decided that ARAF should not be reinstated, a decision that was endorsed by both the IOC and WADA, and that no other ARAF staff (such as staff and athlete support staff) could participate in competitions of the IAAF while ARAF was suspended. (IAAF, 2016).

At the same time the Russian Olympic Committee and individual athletes from Russia individually submitted arbitration requests to the Court of Arbitration for Sport (CAS) on IAAF decisions. The CAS arbitration panel decided in favor of the IAAF, thus confirming the ban on Russian athletics athletes. (CAS ad hoc Division OG Rio 013, 2016).

Following the release of the IC Report on July 24, 2016, the IOC issued a protocol requiring some conditions that Russian athletes must meet to be eligible to compete in Rio 2016. The main one was the athlete's antidoping record, which should "only reliable international tests". In addition, International Federations (IF), which were responsible for deciding which athletes were eligible to participate in the Olympic Games, were advised by the IOC that the absence of positive doping results would not be considered sufficient to establish that an athlete does not use it. (IOC, 2014a).

The IOC would accept Russian athletes for participation in the Rio Games only if the IF was convinced that the evidence provided met the IOC conditions and IF determination was confirmed by a specialist on the list of CAS officials. Russian athletes who were previously sanctioned for doping, or who were unable to meet IOC criteria, would not be allowed to compete at the Rio 2016 Games. (IOC, 2014a).

The consequences for the Russian Olympic Committee were the $30 \%$ drop in the size of its team that was eligible for the Rio 2016 Games. As announced by the IOC on 4 August 2016, the Russian Olympic Team (ROC) with 271 athletes; the original entry list for the included 389 athletes. However, the number of Russian athletes could still change. On August 8, 2016, CBS News reported that seven Russian swimmers who had been banned from participating in the Rio 2016 Games were allowed to compete, although the International Swimming Federation (FINA) did not fully explain why, one of the Russian swimmers participated in the semifinal of the 100 meters shallow on August 7, 2016. (CBS, 2016).

The conflict of interests of the IFs, with the IOC and WADA, allowed this ethical misalignment in dealing with the OS. Athletes, coaches and sports leaders when they are sanctioned resort to the organs that, even without the specific competence in the matter, find themselves in a position to generate an official opinion, by the power they have with the IOC, discrediting the institutions that control doping in the OS. 
On June 21, 2016, the IOC convened an Olympic Summit, aiming guaranteeing "equal conditions for all participating athletes" at the Rio 2016 Games, recommended that the IFs and the National Olympic Committees (NOC) take all necessary measures to prevent "doped athletes" from participating in the Rio 2016 Games, and to refrain from requesting accreditation for the matches for "anyone currently involved in an anti-doping rule violation." (IOC, 2016a).

The Olympic Sport also stated that Russian and Kenyan ${ }^{1}$ athletes are not entitled to "presumption of innocence" because neither country complies with the CODE and there were "substantial allegations" about the sports organizations of those countries.

In the spring of the northern hemisphere 2016, the IOC decided to re-test samples from the 2008 Beijing and London 2012 Games. Two of the planned four rounds of re-tests occurred. (IOC, 2016b). With focus on the athletes who could participate in the Rio 2016 Games, 454 samples obtained during the 2008 Beijing Games were tested again in the first round. The results indicated that 31 athletes from 6 sports and 12 countries had a positive result. The second round involved re-testing 386 samples and resulted in 30 positive results, of which 23 were from athletes who received a medal during the Beijing Olympics, these positive results was from 4 sports and 8 countries. (IOC, 2016b).

On May 27, 2016, the IOC announced that in the first round of re-tests, analysis of 265 samples of the 2012 London Games resulted positive for 23 athletes from 5 sports and 6 countries. The second round resulted in 15 positive tests from a set of 138 samples involving 2 sports and 9 countries. The re-examination of 1,243 samples of the Beijing and London Games in rounds one and two resulted in 98 positive tests. (IOC, 2016b).

The implications of this situation, including the IC Report, go beyond the consequences for Russian sports organizations, athletes and officials. Other athletes (in particular, non-Russian athletes) are interested in the results of research and related subjects. Following the release of the IC report in November 2015 and prior to the June 2016 IAAF decision to maintain the ARAF suspension, several organizations representing the interests of Olympic athletes shared their concerns with the IOC and WADA leaders.

Generally, representatives of athlete organizations, in separate communications, expressed dissatisfaction with the actions of WADA or the IOC and advocated that both organizations do more to protect clean athletes and to protect sports in all countries. A common theme was the call for expanded research on other countries and other Russian sports. As the chairman of the WADA Athletes' Committee said in a speech, the IC report noted the "total and absolute untruth" of the orchestrated doping system in Russia serving only athletic athletes. (WADA, 2016a).

One month before the IAAF decision on ARAF, the presidents of the IOC Athletes Commission and the WADA Athletes' Committee expressed in a letter to the IOC and WADA presidents the prospect of their "shared constituency:" in these times, the athlete's confidence in the anti-doping system, the WADA and the IOC was broken. Although the IAAF decision to suspend ARAF banning Russian athletes from competing in the Rio 2016 Games was welcomed by the IOC Athletes Commission and the WADA Athletes Committee, the athletes did not reactwell, soon after IOC's decision not to impose a total ban on Russian athletes.

\footnotetext{
1 WADA stated on May 12, 2016, that the Kenya Anti-Doping Agency is not in compliance with the Code. Also in 2016, a news article reported that the chairman of the Kenya Athletics Association has requested bribes from two Kenyan athletes in exchange for reducing their doping suspensions. HALCHIN, L.E; ROLLINS, J.W. (2016).
} 


\section{PROTECTING CLEAN ATHLETES}

The IC Report emphasizes the need to strengthen efforts to protect clean athletes, which was initiated by the IOC at the end of December 2014. Following the IOC's 127th Session, held on December 9, 2014, the IOC changed its philosophy of doping and called for greater independence of WADA. (IOC, 2014b).

On August 2, 2015, the new Olympic Charter states that the IOC's role is: "to protect clean athletes and the integrity of sport by leading the fight against doping." Previously, the Charter stated that the IOC's role in doping was: "to lead the fight against doping in sport".Explaining his change of philosophy, the IOC wrote, that: "the Olympic Movement is all about clean athletes, they are our best ambassadors, models, and our treasure. So, we have, above all, to protect clean athletes, against doping, manipulation and corruption, we have to change our way of thinking, we must consider every penny in fighting these evils not as an expense but as an investment in the future of the OS, we must realize that the capture of fraud is extremely important, but only a means to an end: the protection of clean athletes". (IOC, 2015a).

Since the change of the Olympic Charter, the IOC has taken measures to improve the protection of clean athletes. At the Olympic Summit in October 2015 the IOC proposed that athletes' tests be independent of sports organizations and requested that WADA lead a task force to study the proposal for WADA itself to take responsibility for the test. (IOC, 2015a).

In December 2015, the IOC Executive Board unanimously adopted a statement which included proposals for WADA and CAS. The executive board proposed that WADA establish an independent entity for testing and management of results, that the new entity should include a unit dedicated to collecting information and that "sports organizations should transfer their doping control operations to this new organization." (IOC, 2015b).

The proposal of the IOC Executive Board involving CAS indicated that the court should be the agency that proclaims doping sanctions. This change, according to the board, would centralize the sanctions system and be cost-effective, creating a more harmonized anti-doping system across all sports and all countries. (IOC, 2015b). Finally, the IOC invited WADA to convene a "World Conference on Doping" in 2017, but before that had a great test: the XXXI Summer Olympics - Rio 2016.

Table 3 - Disqualified Athletes of the Rio 2016 Olympic Games.

\begin{tabular}{|c|c|c|c|c|c|}
\hline Athlete & Country & Sport & $\begin{array}{l}\text { Prohibited } \\
\text { Substance }\end{array}$ & Medal & Test details \\
\hline Izzat Artykov & Kyrgyzstan & $\begin{array}{l}\text { Weightlifting } \\
69 \mathrm{~kg}\end{array}$ & Strychnine & $\begin{array}{l}\text { Bronze } \\
(69 \mathrm{~kg})\end{array}$ & $\begin{array}{l}\text { Positive test for strychnine and } \\
\text { loss of medalannounced by } \\
\text { CAS. }\end{array}$ \\
\hline Chen Xinyi & China & $\begin{array}{l}\text { Swimming } \\
100 \text { meters } \\
\text { butterfly }\end{array}$ & Hydrochlorothiazide & & $\begin{array}{l}\text { Tested positive for the diuretic } \\
\text { hydrochlorothiazide applied for } \\
\text { sample B to be tested and the } \\
\text { hearing to be performed. }\end{array}$ \\
\hline $\begin{array}{l}\text { Anastassya } \\
\text { Kudinova }\end{array}$ & Kazakhstan & $\begin{array}{l}\text { Athletics } \\
400 \text { meters }\end{array}$ & Drostanolone & & $\begin{array}{l}\text { Proof out of competition in } \\
\text { Almaty, Kazakhstan, on July 13, } \\
2016\end{array}$ \\
\hline
\end{tabular}




\begin{tabular}{|c|c|c|c|c|c|}
\hline \multirow[t]{2}{*}{$\begin{array}{l}\text { Kléber } \\
\text { Ramos }\end{array}$} & \multirow[t]{2}{*}{ Brazil } & \multirow[t]{2}{*}{ Cycling road } & \multirow[t]{2}{*}{ EPO CERA } & & $\begin{array}{l}\text { Pre-competition test July } 31 \text { and } \\
\text { out of competition test (blood } \\
\text { and urine) August } 4 \text {. }\end{array}$ \\
\hline & & & & & $\begin{array}{l}\text { Temporarily suspended by the } \\
\mathrm{UCl} \text { on } 12 \text { August. }\end{array}$ \\
\hline \multirow{3}{*}{$\begin{array}{l}\text { Serghei } \\
\text { Tarnovschi }\end{array}$} & \multirow[t]{3}{*}{ Moldavia } & Canoeing & \multirow[t]{3}{*}{ GHRP-2 } & \multirow{3}{*}{$\begin{array}{l}\text { Bronze } \\
(\mathrm{C}-1 \\
1000 \\
\mathrm{~m})\end{array}$} & Pre-competition test result. \\
\hline & & C-1 $1000 \mathrm{~m}$ & & & Temporarily suspended on \\
\hline & & C-2 $1000 \mathrm{~m}$ & & & August 18. \\
\hline $\begin{array}{l}\text { Chagnaadorj } \\
\text { Usukhbayar }\end{array}$ & Mongolia & $\begin{array}{l}\text { Weightlifting } \\
56 \mathrm{~kg}\end{array}$ & $\begin{array}{l}\text { Exogenous } \\
\text { testosterone }\end{array}$ & & $\begin{array}{l}\text { IOC out of competition on } \\
\text { August } 7 \text {. }\end{array}$ \\
\hline
\end{tabular}

Source: IAAF, 2016; CAS, 2016; UCI, 2016.

Table 4 - Athletes who were selected for the Games but were suspended before the games start.

\begin{tabular}{|c|c|c|c|c|}
\hline Name & Country & Sport & $\begin{array}{l}\text { Prohibited } \\
\text { Substance }\end{array}$ & Test details \\
\hline $\begin{array}{l}\text { Silvia } \\
\text { Danekova }\end{array}$ & Bulgaria & Athletics & EPO & $\begin{array}{l}\text { Provisionally suspended after a failed test of } \\
\text { sample A, given a few days after arrival in Brazil. }\end{array}$ \\
\hline \multirow{2}{*}{$\begin{array}{l}\text { Theodora } \\
\text { Gianeni }\end{array}$} & \multirow[t]{2}{*}{ Greece } & Swimming & \multirow[t]{2}{*}{ Not disclosed } & \multirow{2}{*}{$\begin{array}{l}\text { Sent home on the day of the opening ceremony of } \\
\text { the games after failing a pre-game test held on } \\
\text { July } 25 .\end{array}$} \\
\hline & & $\begin{array}{l}50 \text { meters } \\
\text { freestyle }\end{array}$ & & \\
\hline \multirow{2}{*}{$\begin{array}{l}\text { Antonis } \\
\text { Martasidis }\end{array}$} & \multirow[t]{2}{*}{ Cyprus } & Weightlifting & \multirow[t]{2}{*}{ Not disclosed } & \multirow{2}{*}{$\begin{array}{l}\text { Sent home on the day of the opening ceremony of } \\
\text { the games after failing a pre-game test held on } \\
\text { July } 25 \text {. }\end{array}$} \\
\hline & & $85 \mathrm{~kg}$ & & \\
\hline $\begin{array}{l}\text { Michael } \\
\text { O'Reilly }\end{array}$ & Ireland & $\begin{array}{l}\text { Boxing } \\
\text { average } \\
\text { weight }\end{array}$ & Not disclosed & $\begin{array}{l}\text { He admitted taking a diuretic supplement given to } \\
\text { him by someone else. }\end{array}$ \\
\hline $\begin{array}{l}\text { Narsingh } \\
\text { Pancham } \\
\text { Yadav }\end{array}$ & India & $\begin{array}{l}\text { Wrestling } 74 \\
\mathrm{~kg}\end{array}$ & Metandienona & $\begin{array}{l}\text { Originally cleaned to compete by the National } \\
\text { Anti-Doping Agency of India after positive tests on } \\
\text { June } 25 \text { and July } 5 \text {. WADA's appeal was upheld } \\
\text { by CAS on Aug. 18, with a four-year suspension. }\end{array}$ \\
\hline $\begin{array}{l}\text { Adrian } \\
\text { Zieliński }\end{array}$ & Poland & $\begin{array}{l}\text { Weightlifting } \\
94 \mathrm{~kg}\end{array}$ & Nandrolone & Waiting for sentence \\
\hline $\begin{array}{l}\text { Tomasz } \\
\text { Zieliński }\end{array}$ & Poland & $\begin{array}{l}\text { Weightlifting } \\
94 \mathrm{~kg}\end{array}$ & Nandrolone & $\begin{array}{l}\text { Sent home early in the Olympics after testing } \\
\text { positive at the Polish Championships in July. }\end{array}$ \\
\hline
\end{tabular}




\section{OLYMPIC GAMES RIO 2016: THE WORST ANTIDOPING IN HISTORY}

Anti-doping control at the Rio 2016 Olympic Games was marked as the "worst" of all Games. After the sample collection process was compromised by a wave of non-appearances of athletes, lack of training and numbers of volunteers and testers, and a series of safety lapses.

Telegraph Sport correspondent Ben Rumsby, said efforts to keep the first Olympics Gamesafter Russian doping scandal were in danger of being destroyed by the Games' organizational chaos in Brazil. The integrity of the entire process was under threat due to the severe shortage of staff, with only half of the volunteers recruited to help carry out the official doping control protocols developed. The organizers also admitted that unauthorized persons had access to restricted areas during the drug testing process, although they denied that they had failed to ensure anti-doping at the Games was irreproachable. (Rumsby, B. 2016).

Rio 2016 Games began less than three weeks after the publication of a condemnatory report in which Russia was found guilty of state-sponsored doping at the 2014 Winter Olympics. An investigation by McLaren also has discovered a sample exchange plan orchestrated by the Kremlin at the Sochi anti-doping laboratory. (McLaren, 2016a, 2016b).

In this sense, the Rio Games was the opportunity to restore the credibility of the drug test process, but it appears that this has not happened, only officials "full of resources" in doping control from countries such as the UK have prevented integrity collection was compromised.

Another alarming finding was that a large number of volunteers had picked up their uniforms at the start of the Games to never go back, and others came in every day just to enjoy "free meals." Some doping control officials described "throwing in the towel "and returned home in the midst of claims they made, for having to pay for taxis from their own pockets to get to the sites to collect samples in time.

Rumbsey (2016), also reported that Rio 2016 communications director Mario Andrada said he was unaware of any problems caused by the shortage of personnel but admitted that volunteers allowed safety breaches to occur during doping control in certain locations:

"At the start of the Games, people complained about the lack of volunteer training", he said. "Not all the halls leading to the doping areas were cleaned, the volunteers were not strong enough and some people were very close to areas that should be restricted. We've fixed that problem."

The Rio 2016 Organizing Committee has admitted that of its 70,000 planned volunteers have been reduced to a staff of 56,000 due to budget cuts. And of these only about $70 \%$ actually worked. Unpaid workers are vital to the successful operation of the sample collection process at an important event such as the Olympic Games, in which about 5,000 drug tests will be held. Volunteers are often employed as accompanying athletes to doping control to ensure that the tests are not avoided or circumvented in any other way. (Rumsby, B. 2016).

Michele Verroken, the UK's former anti-doping chief, told Telegraph Sport: "It is extremely disappointing that anything that happened earlier continues to occur at the Olympic Games. We came to the situation where we were lucky to catch anyone." (Rumsby, B. 2016). 
The same reporting highlights Kenya, which not only appeared on the podium, but in another scandal related to the drug test process was evidenced in Rio 2016, when Kenyan athletic trainer John Anzrah was caught taking Ferguson Cheruiyot Rotich's credential when the 800 meters runner was being searched to provide a sample. Anzrah was sent home but denied passing by Rotich in order to test him, insisting that he borrowed the credential to get a free meal. (Rumsby, B. 2016).

Brazil stopped conducting drug tests on its top athletes one month before the Games after its anti-doping laboratory had its accreditation suspended. This suspension was lifted in time for the Olympics and during the first week of the games the laboratory had processed 3,743 samples.

Andrada insisted that there was no flaw in the process before the athletes' urine and blood arrived in the lab "there was no impairment in any way or outside of the test procedures, we have zero tolerance for doping," he added. "The Doping operation is working as it should be and the risk is zero of an endemic problem or system problem occurs, drug testing in the Games is being monitored by an independent observer group named by World Anti-Doping Agency." (Rumsby, B. 2016).

"WADA is not involved in the process of doping control in the Games, except through an independent observation mission that will publish its report after the Games. The process of doping control in the Games is under the responsibility of the IOC, working in collaboration with the organizing committee. It is not WADA's role to comment on doping control issues in the Games until the IC Report is published." (Rumsby, B 2016).

\section{AFTER THE RIO 2016 GAMES WADA REVEALS THAT UP TO 50\% OF THE DRUG TESTS HAD TO BE ABORTED}

The WADA report on the anti-doping operation employed at the Rio 2016 Olympic Games indicated "serious failures." Up to half of all planned drug tests were aborted because athletes could not be found. The 55-page report from WADA's IC accused the Rio 2016 anti-doping department's management team of "lack of coordination," which has contributed to the almost uncontrollable strain of drug testing at competition places and Athletes' Village. (WADA, 2016b).

In addition to a "lack of coordination and unified approach" between Rio 2016 anti-doping department management, the report also blamed failures on "budget and operational cuts", which meant fewer resources for the fight against doping. Tensions between the Rio 2016department management and the Brazilian AntiDoping Agency, with the significant personnel changes in the anti-doping department of Rio 2016 a year before the Games, contributed to an amateur approach to the problem.

The report was incisively critical of the lack of support, training and information given to test attendants whose job it was to notify athletes of anti-doping controls. "Attendants were provided little or no whereabouts information for test athletes who were out of competition in the Athletes' Village, most of the time they had to turn to the delegations and / or athletes of the same delegation they were looking for", says the report. (WADA, 2016b).

In addition, when initial attempts to find an athlete in their room were unsuccessful, attendants often lacked the training and / or confidence to follow up with more questions and effort to find the athlete elsewhere in the Village. Ultimately, many test athletes simply could not be found and the mission had to be aborted. In some days up to $50 \%$ of planned target tests were aborted. 
The report also pointed to the lack of support for the companions, for example: those who went out looking for athletes and spent much time on the mission, when they returned they no longer found food, this led many to not collaborate properly. (WADA, 2016b).

About transportation facilities to allow doping control agents to travel their meeting places were "often inadequate, or even non-existent." Observers said that computers and printers that needed to receive and print "mission orders" sometimes did not work, even when computers were running, not enough accounts and login were given to doping control personnel. (WADA, 2016b).

No out-of-competition test was conducted in football. According to the same report, little or no competition testing has been done on many sports and high-risk tests such as weightlifting. The Independent Observers found this "surprising". Nearly 500 fewer drug tests than planned were conducted in Rio 2016, according to the report. The plan was to do 5,380 tests in total, but in reality, only 4,882 were performed. And of the 450 blood tests on the athlete's biological passport, only 47 were performed. (WADA, 2016b).

The number of athletes tested in the total in the Games was $3,237,28.62 \%$ of the number of participants. In the end the report goes on to praise the individual effort undertaken by the volunteers who actually embraced the task. Affirming that, had it not been for its personal "on-the-ground" staff, the Games' anti-doping program almost certainly collapsed due to its initiative, tenacity and professionalism in the face of great difficulties, the numerous problems identified were corrected and the collection of samples was conducted to ensure the identity and integrity of the samples, the report says. (WADA, 2016b).

Particular praise was also paid to the managers of the anti-doping control stations who, even though they did not receive on-site training on the role to play, did not have site-specific information and did not have specific guidelines for each sport, often arrived at the site for the first time already on the first day of testing, where they were presented with an insufficient number of companions to carry out the planned tests in the best possible way.

Despite its condemnatory criticism, the WADA report also commended the Brazilian Doping Control Laboratory, which had been suspended before the start of the Games for failing to meet international standards. The report confirmed that the laboratory was well equipped, operated very safely and efficiently, and now represents an exceptional legacy of the Games for the anti-doping movement in South America.

\section{BACK TO RUSSIA: THE MEETING OF LIMA 2017}

The first group of Russian athletes suspected of benefiting from the efficient doping state program for the 2014 Sochi Winter Games may now, with the approach the 2018 PyeongChang Games in South Korea, face sanctions, including the prospect of expulsion for these games.

Denis Oswald, a Swiss member of the IOC Executive Council who led one of two investigations into the Russian doping program, told committee members at the annual meeting of the International Olympic Committee (IOC) executives held in Lima, Peru, from 13 to 17 October, September 2017, which hopes that the investigation will be completed by the end of the year and that the athletes involved will be penalized. He also pointed out the perspective of these athletes who were medalists in Sochi having to return the medals and be banned. "We feel we have found several elements to sanction a good number of athletes," Oswald said. (Panja, T. 2017). 
At the Sochi Games, Russia was suspected of tampering with urine samples from athletes who tested positive for anti-doping. The leader of the investigation stated that the delay in testing Sochi samples stemmed from a difficulty in finding a suitable method to detect whether the special urine collection vessel, which were considered by the tamper-proof protocol, had been tampered with. "In a few days we will have the results of the first 50 samples, and then we can proceed." (Panja, T. 2017).

Today this possible sanction of Russian athletes can "cool" the Olympic Flame as it did in the Rio 2016 Games, when news of the doping scheme emerged and prompted a number of sports federations to prevent Russian athletes from attending the Games.

The competence of the Russian doping scheme was revealed last year when World Anti-Doping Agency researcher Richard McLaren reported before the start of the Rio 2016 Games how the state machine worked in the production of its athletes. His report used forensic analysis to corroborate the testimony of the former head of Russia's national anti-doping laboratory, Grigory Rodchenkov, who described how he and Russia's intelligence helped national Olympic athletes to use banned substances that improve performance at the Sochi Games. (McLaren, 2016b).

The report, produced by McLaren, sought to break through the borders of Russian doping schemes beyond the Sochi games and identified about 1,000 athletes involved. At the moment, a number of interests are represented by companies, brands, sponsors and countries that can not fail to profit from the "Olympic business". AND...

The report also suggested that proving the involvement of agencies and athletes involved will likely be difficult. The World Anti-Doping Agency has released 95 of the first 96 athletes whose doping cases in competitions have been reviewed and it was not possible to prove the positive re-test. It was also reported that the amount of evidence in the athletes varied widely, so the sports authorities were instrumental in seeking additional evidence to reinforce the lawsuits unchained.

This raised a debate in the sporting world about whether Russia's schemes succeeded in destroying evidence since the cases investigated so far could not attest and punish the first 96 athletes investigated. "The available evidence was insufficient to support the allegation of anti-doping rule violation against these 95 athletes," agency director general Olivier Niggli wrote in the internal report obtained by The New York Times. The report does not identify any of the 96 athletes. (Ruiz, 2017).

In an interview Niggli said: "The system was very well organized," referring to the trickery co-ordinated by Russia. "Achieving evidence of the doping scheme years after that has generated the problem that the evidence obtained is limited." (Ruiz, 2017).

Richard McLaren also reported that the cases would be difficult to track because of Russia's failure to provide data and the "practice of destroying samples" since it proved positive in the re-tests, that would be to attest to the veracity of the scheme. (McLaren, 2016b).

Other data are important to report: the sports authorities charged with lawsuits against the 95 freed athletes appear not to have followed the clues. No one asked for interviews with Dr. Grigory Rodchenkov who was head of RUSADA's laboratory and fled Russia after denouncing the operation of the state machine in the doping program, whose testimony resulted in the report of the McLaren investigation, which showed his professional action in the production of super athletes and the destruction of evidence. (Ruiz, 2017). 
Jim Walden, attorney for Dr. Rodchenkov questioned in defense the fact that the sports authorities did not request the testimony of his client and claimed that he was not available, that today he lives hidden in the United States under protection of the Department of Justice and under warrant of Russia, "The alleged unavailability of Dr. Rodchenkov was cited as one of the reasons for the closure of investigations of athletes," the lawyer further stated that his client was willing to cooperate, "only an Olympic investigator request an interview." (Ruiz, 2017).

Once the McLaren report described Russia's doping program, the sanctioning of athletes fell into the global sports bureaucracy. IFs were imbued with examining their own athletes and punishing when justified. WADA would review decisions taken by IFs and determine whether to approve or respond. This process has generated the 95 cases the agency has agreed to file. (Ruiz, 2017).

Some authorities have expressed concern about conflicts of interest among IF leaders because they may be inclined not to punish their athletes. WADA chief, Craig Reedie, who is also a member of the IOC, was asked about his dual role as promoter of the Olympic brand and at the same time have to seek evidence that could overshadow it. IFs and the IOC have maximum authority over sanctioning athletes, but the declarations of the anti-doping regulator are influential, and the agency has the power to appeal cases. (Ruiz, 2017).

In defense Niggli emphasized that investigations into other athletes involved in the doping system continue, and that authorities needed to follow the strongest evidence, to bring them to the world's sporting arbitration court. "Bringing a weak or poorly prepared case to court could adversely affect the outcome of all others," he said. (Ruiz, 2017).

To that end, the IOC opened disciplinary proceedings against Russian athletes, along with the anti-doping regulator, which had indicated Russia's non-participation in the Rio 2016 Olympic Games, published 1,166 evidences of Russia's schemes. While the evidences including e-mails, documents, forensic and scientific analyzes effectively proves a doping system, Niggli said the evidence does not necessarily translate into the judgment of the athletes McLaren identified as benefiting from the program. (McLaren, 2016b).

Of the 96 cases evaluated, only one athlete was successfully sanctioned because the authorities recovered an incriminating urine sample from Dr. Rodchenkov's former laboratory, in response the Russian government prevented entry into a specific area of the laboratory that contained other samples.

At the Rio 2016 Games, doubts about which athletes would participate continued until the day before the event. This whole problem was aggravated by the fact that the president of the IOC favored individual judgment at the expense of collective responsibility and consequently diminished the impact of the Russian state scheme. He commented that the decision on Russia's participation in Rio 2016 would respect the statements made by the IFs separately. Some federations, such as cycling, rowing and athletics, have adopted unrestricted bans, while others allowed for the participation of athletes who could prove they were clean. (Ruiz, 2017).

None of the Winter Sports IFs supported a total ban on Russian athletes at the 2018 Pyeongchang Games, showing the strength of Russia at the Winter Games as well. The non-participation of the Russian Federation would obfuscate the "brilliance" of games even with athletes under the shadow of doping. This position seems to have been shared by the majority of IOC members at the meeting of the Executive Committee in Lima. "For me, the important thing is that innocent athletes should be there," said Tunku Imran, a member of the IOC representing Malaysia. (Ruiz, 2017). 
After the meeting of the IOC Executive Committee in Lima, what transpired was that any possible penalty against Russia will have to wait until the conclusion of a more comprehensive report on the scheme, which is being developed by the team of former President Samuel Schmid of Switzerland, current chair of the IOC Disciplinary Commission (DC). In his communication to the Committee on the McLaren report, he stated:

1. As chair of the IOC DC, it is a great honor to have the opportunity to present my interim report to the Session. At this stage, as the investigation is not finalized and as all information is very sensitive, DC welcomes your understanding that, at this time, no detailed information can be disclosed. However, the DC can keep the session informed about the current state of the work done so far and the next steps.

2. Since the last session of the IOC in Rio de Janeiro, DC has initiated a large number of hearings and exchanges of written information with several persons capable of providing appropriate information about the facts as well as about the general sports system in Russia. For reasons of confidentiality, the list of such persons may not be disclosed.

3. At the same time, the DC made a detailed and in-depth analysis of the WADA IC Reports, the IP Reports and all the evidence (EDP - published by IP as an appendix to the second report published on December 9, 2016). This analysis was consolidated after the publication in May 2017 of EDP commissioned by WADA. These documents cover the period from August 2012 to August 2015, except in February 2014.

4. The Prof. Richard McLaren helped with this DC, explaining the various EDPs and the content of the confidential elements provided by various witnesses collected by IP. The content and truthfulness of confidential witnesses are currently being evaluated in the light of the objective and impartial elements available to the DC.

5. The methodology of forensic examination of marks and scratches on urine sample containers has been finalized and validated at the Forensic Department (ESC) of the University of Lausanne (UNIL) and samples of the Sochi Olympic Games are being analyzed. The results will be communicated to the two DCs during the autumn of 2017.

6. The outcome of this forensic examination is one of the key elements for the evaluation of witnesses on the specific period of the Winter Olympic Games in Sochi; therefore, the DC schedule depends on these results.

7. Once the remaining hearings and the latest evaluations have been held, the $\mathrm{DC}$ will inform the IOC Executive Board. It is difficult at this stage to define a detailed timeline; however, the Executive Board requested that the report be finalized before the 2018 Winter Olympics in PyeongChang. (Lima, September 15, 2017). (IOC, 2017).

Russia does not seem to mind the outcome of the investigations and remains confident in bringing a full contingent of athletes to Pyeongchang. "It will be a Russian team with the Russian anthem and the Russian flag," Alexander Zhukov, head of the Russian Olympic Committee, said in an interview. He also denied that there was a state-backed conspiracy to dope athletes, and says he supports the investigations as there is a rehabilitation plan established by the WADA. (Ruiz, 2017).

In contrast, Reedie suggested that probably some penalty will come soon "Alexander is well aware of this," said moments after Zhukov again deny the existence of a national plot to deceive the president of WADA. The Russian case has created tensions within the clean sports movement. A group of 17 anti-doping agencies issued a letter demanding that Russia be excluded from Pyeongchang 2018. "The lack of rapid 
research on the Russian doping scheme poses a clear and present danger to clean athletes worldwide and at the Winter Games of 2018, "said the letter, whose signatories include the anti-doping agencies of the United States and England. (Ruiz, 2017).

\section{AT THE CONCLUSION}

Doping reflects the extraordinary dimension of those who make high-performance sports. Looking for alternatives from the ethical point of view to control the search at the maximum performance should be the way to go. The state of physical, social and psychic well-being is affected by this search. The role of every professional who works with a view to high performance is not only to create the material conditions necessary to increase sports performance, but also with this same ethics to avoid future losses, because the constant search of the limits of the body always supposes the risk.

What other workers dope to achieve higher incomes at work? At the top of the list is the high-performance sport. They forgot that sport was / is a civilizing effort, and as a thread of hope we pointed out that the sportsman is not only the one who strengthened his muscles and developed resistance through sports practice, but also one who by this same practice learned to repress his anger, to be tolerant of his companions, not to take advantage of a vile advantage, to feel intimately as a disgrace the slightest suspicion of a cheating and to bear with a head high and with joy, not only the victory, but also the disappointment of the defeat that is represented here by doping.

\section{REFERÊNCIAS}

AS (2016). Media Release. Court of Arbitration for Sport. Lausanne, Switzerland. Retrieved from: http://www.tas-cas.org

CAS ad hoc Division OG 16/013. (2016). Court of Arbitration for Sport. CAS ad hoc Division OG Rio 16/013 Anastasia Karabelshikova \& Ivan Podshivalov v. FISA \& IOC. Rio de Janeiro, Brazil.

CBS Interactive Inc. (2016). 7 Russian swimmers barred from competing in the Rio Olympics. Retrieved from: https://www.cbsnews.com

IAAF. (2015). Council of the International Association of Athletics Federations. Retrieved from: https://www.iaaf.org

IAAF. (2016). Council of the International Association of Athletics Federations. Retrieved from: https://www.iaaf.org

International Olympic Committee, IOC. (2014a). The fight against doping and promotion of athletes health. Lausanne, Switzerland.

International Olympic Committee, IOC (2014b). IOC Annual Report 2014: credibility, sustainability and youth. Lausanne, Switzerland.

International Olympic Committee, IOC (2015a). Olympic charter. Lausanne, Switzerland.

International Olympic Committee, IOC (2015b). IOC executive board meetings in Lausanne, 8 to 10 december. Retrieved from: https://www.olympic.org

International Olympic Committee, IOC (2016a). Declaration of the Olympic summit. Retrieved from: https://www.olympic.org

International Olympic Committee, IOC (2016b). The IOC takes decisive action to protect the clean athletes - doped athletes from Beijing, London and Sochi all targeted. Retrieved from: https://www.olympic.org

International Olympic Committee, IOC (2017). Current status of work of the Samuel Schmid disciciplinary commission relating to the McLaren report. Retrieved from: https://stillmed.olympic.org 
McLaren, R. (2016a). The independent commission report-Part I. Quebec, Canada.

McLaren, R. (2016b). The independent commission report-Part II. Quebec, Canada.

Oltermann, P. (2014). Russia accused of athletics doping cover-up on German TV. The Guardian. Retrieved from: http://www.theguardian.com

Panja, T. (2017, September 16). I.O.C. Investigation of Russian Doping Could Lead to Sanctioning of Athletes. The New York Times. p. D6.

Ruiz, R. R. (2017, September 13). World Anti-Doping Agency Clears 95 Russian Athletes. The New York Times. p. B9.

Rumsby, B. (2016). Rio 2016 Olympics: Anti-doping branded 'worst' in Games history. The Telegraph. Retrieved from: http://www.telegraph.co.uk

WADA, World Anti-Doping Code (2003). The revised 2015 World Anti-Doping Code is effective as of 1 January 2015. Quebec, Canada.

WADA (2016a). WADA Athlete Committee Statement: Independent Investigation confirms Russian State manipulation of the doping control process [website]. Retrieved from: https://www.wada-ama.org

WADA (2016b). Report of the Independent Observers Games of the XXXI Olympiad, Rio de Janeiro 2016. Montreal, Canada. 